\title{
Perspectives of geothermal water use in the Podhale Basin according to geothermal step distribution
}

\author{
Agnieszka Operacz ${ }^{1}$,ózef Chowaniec ${ }^{2}$ \\ ${ }^{1}$ University of Agriculture in Krakow, Faculty of Environmental Engineering and Land Surveying, \\ Department of Sanitary Engineering and Water Management; al. A. Mickiewicza 21, 31-120 Krakow, Poland; \\ e-mail:a.operacz@urk.edu.pl (correspondingauthor) \\ ${ }^{2}$ Polish Geological Institute - National Research Institute Carpathian Branch; ul. Skrzatów 1, 31-560 Krakow, Poland
}

(C) 2018 Authors. This is an open access publication, which can be used, distributed and reproduced in any medium according to the Creative Commons CC-BY 4.0 License requiring that the original work has been properly cited.

Received: 24 August 2018; accepted: 22 October 2018; first published online: 16 November 2018

\begin{abstract}
At present, hydro-geothermal resources in which waters in bores are the carrier of heat energy have commercial importance in Poland. Geothermal waters should feature the highest possible temperature in the outflow, low mineral content, high capacity and low deposit depth. Even though geothermal energy is included in renewable sources of energy, complete depletion of the deposit is the largest risk in extracting geothermal waters. This is why these waters should also feature deposit renewability. There are currently several geothermal provinces with beneficial geothermal conditions in Poland, with the area of the Podhale Basin in the Inner Carpathians region being regarded as the most promising. The Podhale deposit also meets all of the above listed conditions. The possibility of using hydrothermal energy in Poland is practically available throughout the country, but operational use of hot groundwater must be profitable for investors. From another point of view, the environmental impact of such investments should be minimized. This paper is concerned with the special variety of temperature of geothermal waters extracted in the area of the Podhale Basin, which is the basic aspect in using deposits of this type.
\end{abstract}

Keywords: geothermal aquifers, Podhale Basin, geothermal step, prospective areas, Poland

\section{INTRODUCTION}

Geothermal energy is considered to be a renewable source of energy. Poland adopted the European Union obligations (Directive 2009) in terms of the use and promotion of energy from renewable sources. Thus, a minimum $15 \%$ share of energy from renewable sources in the total consumption of gross energy in 2020 and $20 \%$ in 2030 was recognised as the general national objective within the "Energy Policy of Poland up to 2030" (Obwieszczenie 2010).

The development of renewable power engineering in Poland, including geothermal energy, may contribute to the satisfaction of energy needs and becoming independent of importing energy, as well as reducing the current level of emissions of greenhouse gases (Igliński et al. 2012). However, using resources of geothermal waters must be technically possible and economically justified. Given the fact that water temperature plays a key role in the space-heating industry, especially from the economic point of view, temperatures ranging from less than $20^{\circ} \mathrm{C}$ to $60^{\circ} \mathrm{C}$ are the best for technical solutions (i.e. the waters commonly found in Southern Poland) (Bujakowski \& Barbacki 2004).

The construction and start-up of a geothermal heat plant system requires determination 
and substantial financial means, which effectively discourages prospective investors (Igliński et al. 2016). Geothermal waters in Poland are characterised by high mineralisation, which exacerbates the corrosion of machinery. In extreme cases, there is a problem with pumping geothermal water back to the earth. The greatest problem of the Polish geothermal energy sector is the lack of green certificates, which are available to other renewable energy sources (Szewczyk \& Gientka 2009).

The key characteristic values of geothermal reservoirs are: achievable borehole capacity, mineralisation of water in the deposit and temperature of water at the outflow. The approach in Poland is that highly favourable exploitation conditions of geothermal waters exist within the Podhale Basin due to its positive geological structure, the high temperature of water at the outflow (up to $86^{\circ} \mathrm{C}$ ), low mineralisation (up to $3 \mathrm{~g} / \mathrm{dm}^{3}$ ), high capacity (up to $550 \mathrm{~m}^{3} / \mathrm{h}$ from a single intake), renewability of the deposit and easy accessibility of the area (Chowaniec et al. 2001, Małecka 2003).

For successful progress in geothermal development it is necessary to limit investment costs so as to make geothermal energy more competitive and marketable than heat obtained from other sources. Kepinska (2003) ascertained that, with this in mind, emphasis is being placed on the planning and construction of smaller installations that make use of existing wells, ground and shallow aquifers and cascade and/or integrated systems, as well as the larger installations. At the project planning phase, another important question is the evaluation of the directions and manner of utilisation of spent water (Tomaszewska \& Bodzek 2013, Tomaszewska \& Szczepański 2014).

\section{THE SCOPE OF THE STUDY}

Poland is characterised by low-temperature geothermal resources connected mostly with the Mesozoic sedimentary formations (Sokołowski 1973, Barbacki 2012). The short term forecasting for the installed capacity of geothermal electricity in Poland to 2020 is $1 \mathrm{MWe}$ (Bertani 2016). As yet, there is no operational geothermal power-plant in Poland, but a small binary pilot plant at Łódź is under evaluation (Kepinska 2015).
Pursuant to the Geological and Mining Act in Poland (Ustawa 2011), thermal water means groundwater with a temperature not lower than $20^{\circ} \mathrm{C}$ at the outflow from the intake. Geothermal waters, as well as curative waters and brines, are recognised in Poland as useful minerals which determine the method of prospecting and further exploitation according to the national legal regulations.

There are a number of additional procedural regulations in Poland that may block investment, even in conditions when its execution would be technically and economically possible. The creation of installations that are consistent with sustainable development is especially important. Operacz (2017) proposes the term "effective potential" to allow the estimation of the production of energy from renewable sources (for example from hydropower) with the method closest to the real possibilities of execution in line with the sustainable development idea.

The environmental issues in geothermic exploitation are solvable with advanced modelling methods. With specialised software, the chemical composition of geothermal waters may be determined, together with conditions of circulation and volume resources of groundwaters, as well as changeability in space and time (transport) of mass and heat energy may be assessed (Zdechlik et al. 2015). However, the investor often needs easily available and inexpensive information at the preliminary stage of the project that would not require the purchase of software or the development of a model.

This work analyses the spatial distribution of a geothermal step under conditions of the currently conducted exploitation in the Podhale Basin. Such information is useful from the perspective of finding prospective places for new projects, where the mutual relationship of the depth of the intakes and the expected water temperature at this depth is immensely important. For this purpose, the value of the geothermal step was calculated and the map of isolines of this parameter was created. Knowing the value of the geothermal step calculated within the paper may give tangible economic benefits which will allow projects to be planned more effectively. 


\section{PREVIOUS WORKS ON USING GEOTHERMAL WATER}

Resources of geothermal energy are copious: it is estimated that they exceed the current world demand for energy as many as 35 bn times (Lewandowski 2007). Despite this, it seems impossible to replace fossil fuels with geothermal energy, both globally and in the domestic market. The most important argument is the economic unprofitability of carrying out deep boreholes (the 2,000 $\mathrm{m}$ barrier is commonly recognised as the limit for positive economic balance) and too low temperature of borehole waters at the outflow (Huculak et al. 2015, Bugajski et al. 2017).

In Poland, the temperature of geothermal liquids filling in groundwater reservoirs rarely exceeds $100^{\circ} \mathrm{C}$, and the temperature at the outflow is even lower (on the average by ca. $10^{\circ} \mathrm{C}$ ).

The basic criteria that determine the possibilities of using geothermal waters are:

- the appropriate temperature of the abstracted water;

- the capacity of the boreholes and the expected duration of its stable continuation (capacity is measured with continued stream of water abstracted from the borehole and temperature of water; both the former and the latter may change over time; in case of temperature, it may result from the temperature front reaching the abstraction point related to returning water to the deposit);

- the depth from which heat may be taken;

- low content of salt (mineralisation) and substances conducive to corrosion in water;

- the distance of the functioning boreholes from the place of using warm waters.

Temperature of the received waters determines the possibilities of their use (Fig. 1).

The conventional production of electricity requires high-temperature waters, which under national conditions are rarely found at depths that economically substantiate the project. The most frequent use of warm waters in Poland is in balneotherapy and recreation, where temperature of waters should only slightly exceed the normal temperature of the human body.

The innovative method of the management of post-exploitation geothermal waters is in processing them into potable water with a desalination system that combines ultrafiltration with double reverse osmosis (Tomaszewska 2009).

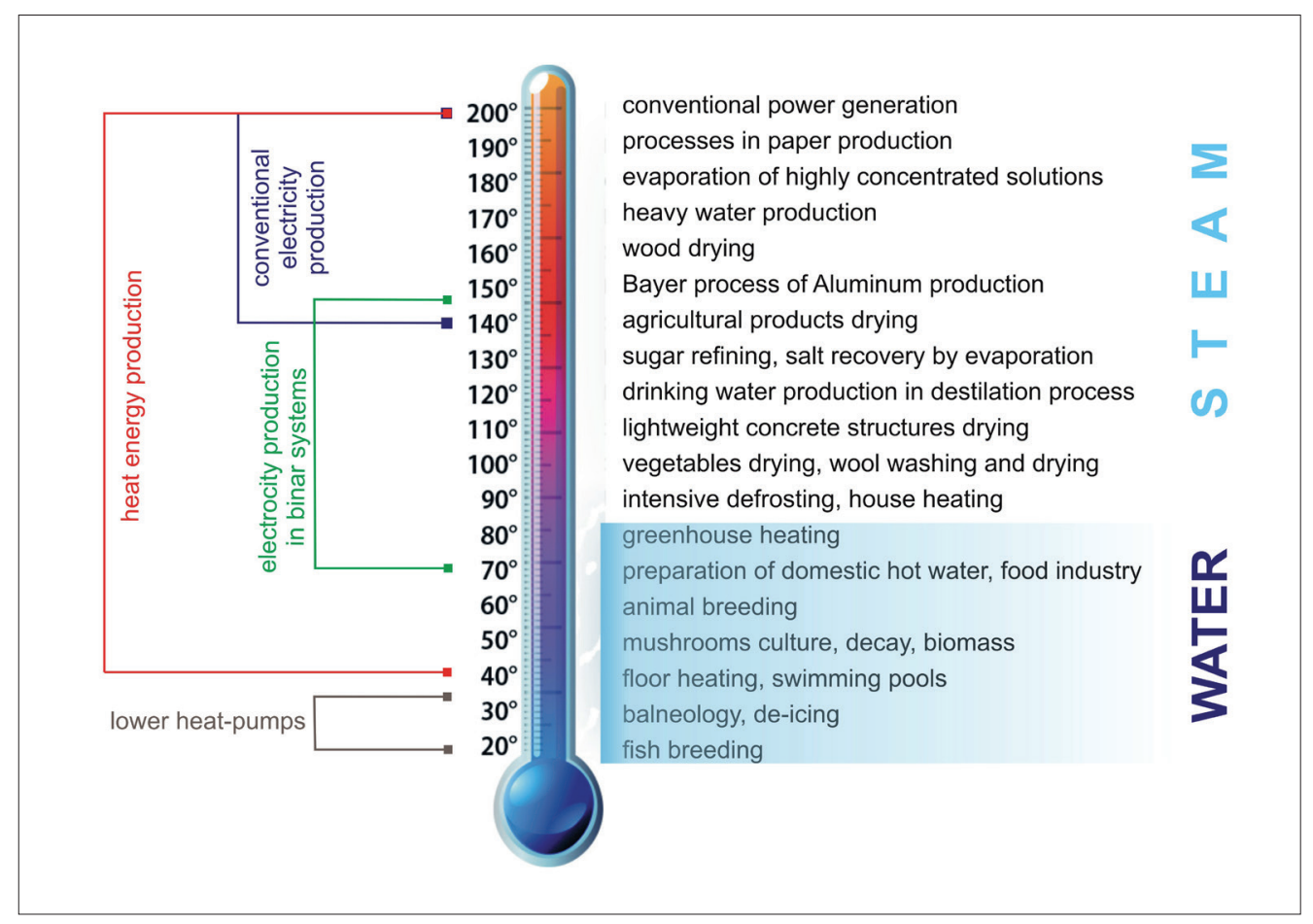

Fig. 1. Modified "Lindal Diagram" (Gudmundsson et al. 1985) 
The economic analysis of the desalination process of geothermal waters showed that the universal determination of the economic profitability of the process of acquiring potable waters from geothermal waters is not possible (Tomaszewska \& Pająk 2012).

The classification based on the manner of geothermal energy utilization is formulated as follows (Bujakowski 2005):

- cold fluids - up to $25^{\circ} \mathrm{C}$, (used as either water or glycol in compression heat pumps);

- low-temperature fluids - from $25^{\circ} \mathrm{C}$ to $60^{\circ} \mathrm{C}$ (used e.g. in absorption heat pumps);

- medium-temperature fluids - from $60^{\circ} \mathrm{C}$ to $100^{\circ} \mathrm{C}$ (used e.g. directly by the user);

- high-temperature fluids and gasses - from $100^{\circ} \mathrm{C}$ to $140^{\circ} \mathrm{C}$ (used e.g. in binary power plants producing electricity and thermal energy);

- very high-temperature liquids and gasses above $140^{\circ} \mathrm{C}$ (used e.g. in conventional geothermal power plants).

\section{GEOLOGICAL}

\section{AND HYDROGEOLOGICAL SETTINGS OF THE PODHALE BASIN}

Taking into consideration geological and structural differentiation, the Inner Carpathians in the area of Poland are divided into three units: the Tatras, the Podhale Basin and the Pieniny Klippen Belt that is the borderline zone between the Inner Carpathians, and the Outer Carpathians (Chowaniec et al. 2001). Particularly favourable hydrogeological conditions exist in the Inner Carpathians, in the Podhale Trough, where there is already one geothermal company using geothermal energy, Geotermia Podhalańska S.A. (Bujakowski \& Barbacki 2004).

The Podhale Basin constitutes a broad asymmetric syncline between the Tatras and the Pieniny Klippen Belt (Fig. 2). It is a reservoir of geothermal waters supplied mostly by precipitation entering the interior of the Tatra massif. These waters, circling in the groundwaters systems from the Tatra massif northwards, are gradually warmed. The impermeable Pieniny Klippen Belt is the borderline of the flow, causing the spreading of the stream of waters south-eastwards and south-westwards. This system causes variation in flow speed which, according to Witczak (Chowaniec et al. 1998) is about several dozen $\mathrm{m}$ /year in the southern part of the basin, down to several meters per year in the zone close to Pieniny. Duration of contact of water with the rock also varies, as reflected in chemistry of waters (Chowaniec et al. 2001). According to some authors, excessive exploitation of geothermal waters in the area of the Podhale Basin can lead to the defreshing of these waters (Kępińska 2009, Kotowski \& Satora 2011, 2012).

The Podhale Basin features mostly artesian conditions, which considerably facilitates the exploitation of geothermal waters. The depth of reservoir rocks ranges from $100 \mathrm{~m}$ to $700 \mathrm{~m}$, with the highest values found in the northern part of the Podhale Basin (Sokołowski 1973). Tectonically, the Podhale system features a complex fault structure resulting from orogenic movements. Low-scale tectonic activities were recorded several times in the Pieniny Klippen Belt. These phenomena affect the permeability of reservoir rocks, causing inflow and mixing of waters feeding geothermal deposits (Kępińska 2009).

Historically, the discovery (in 1844) of the source of the warm waters $\left(20.4^{\circ} \mathrm{C}\right)$ in Jaszczurówka, Zakopane, was the first proof of the existence of hot waters in the Podhale area. It was the sole spontaneous outflow of geothermal waters throughout the Polish Carpathians but it is no longer present (Chowaniec 2009). In 1950s, prospecting was started of the Tatra and Podhale regions with shallow and deep drilling. In November 2001, the first geothermal heat was delivered to customers in Zakopane (Długosz 2003). So far, 15 boreholes have been completed in the Podhale Basin area from which inflows of geothermal waters were obtained (Fig. 3). This geothermal medium is used for heating, recreation, and balneotherapeutic purposes, with the cascade use of geothermal waters increasingly being promoted. Along with the construction of a regional heating network, the Polish Academy of Sciences Mineral and Energy Economy Research Institute Geothermal Laboratory has carried out R\&D on cascade uses covering a wide range of temperatures (Kepinska 2003). These include a lumber-drying unit, greenhouses, fish farms and foil tunnels with heated soil for growing vegetables. The Laboratory is involved in the research and monitoring of geothermal systems, prepares demonstration projects and provides geothermal training (Kepinska 2000). 


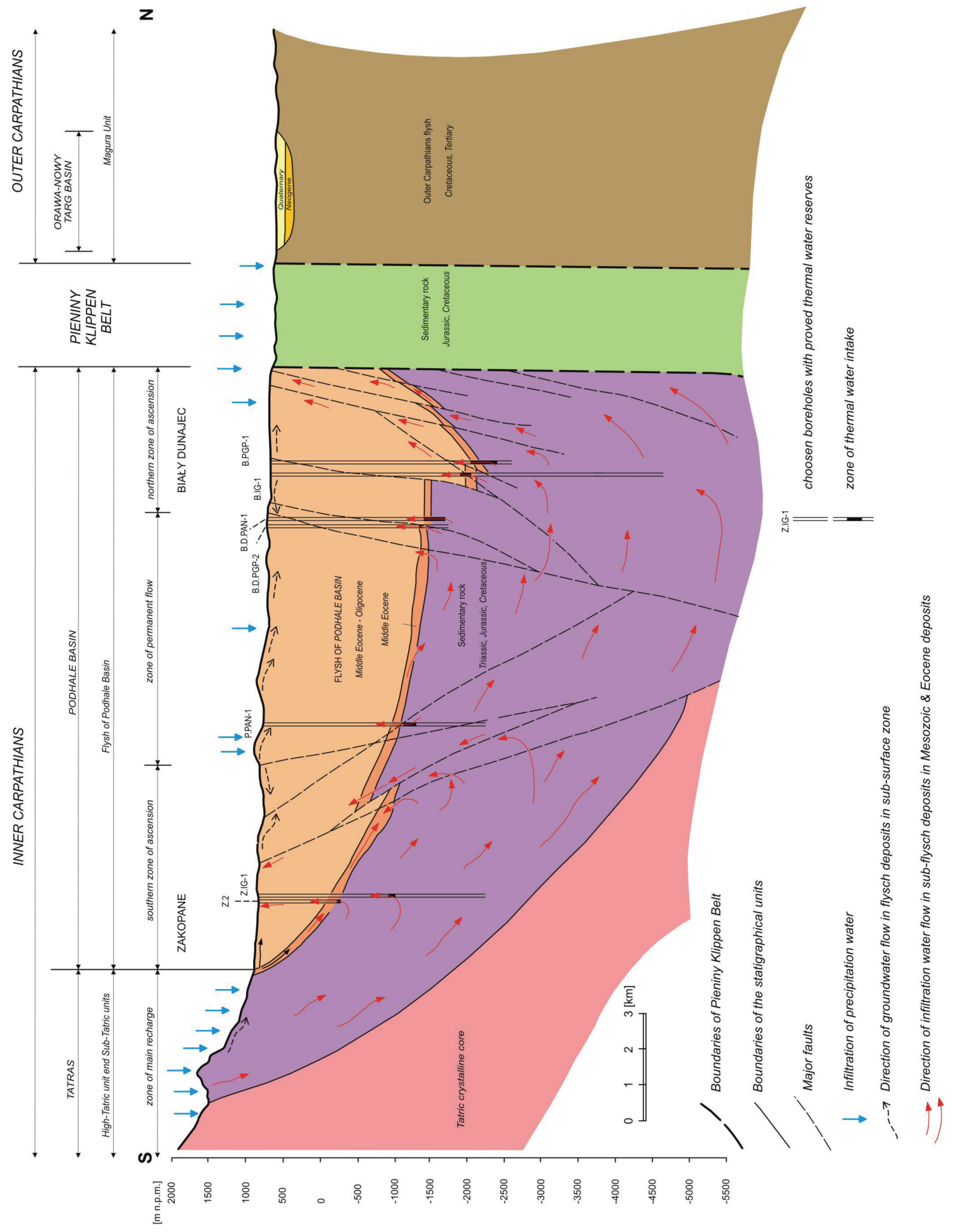

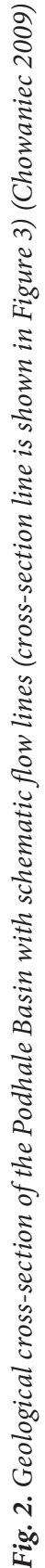



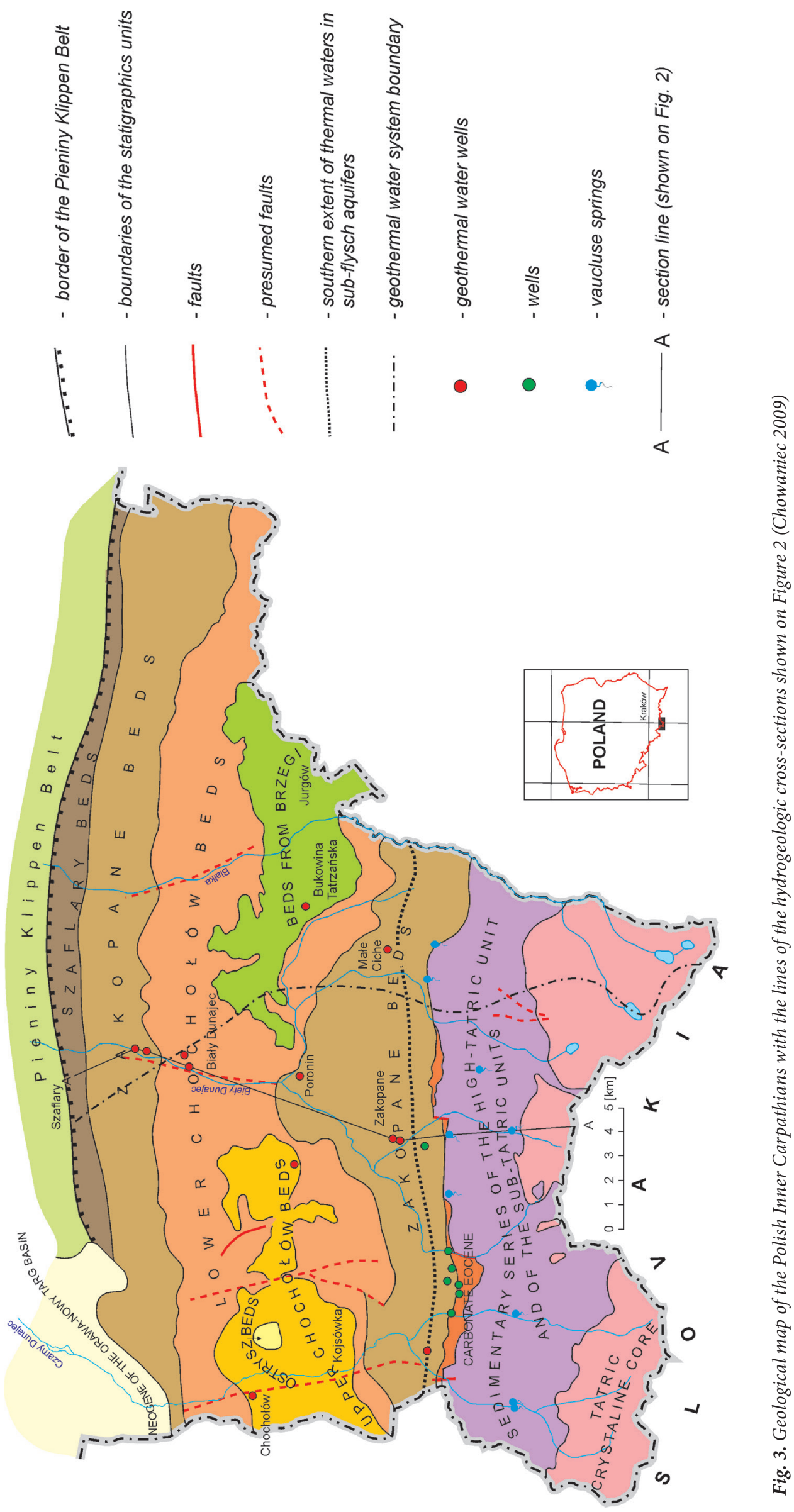
Table 1

Selected parameters of geothermal boreholes in the Podhale Basin

\begin{tabular}{|l|c|c|c|c|}
\hline \multicolumn{1}{|c|}{ Borehole } & $\begin{array}{c}\text { Elevation } \\
{[\mathbf{M A S L}]}\end{array}$ & $\begin{array}{c}\text { Screen interval } \\
{[\mathbf{M G B L}]}\end{array}$ & $\begin{array}{c}\text { Borehole depth } \\
{[\mathbf{M G B L}]}\end{array}$ & $\begin{array}{c}\text { Temperature at the outflow } \\
{\left[{ }^{\circ} \mathbf{C}\right]}\end{array}$ \\
\hline Siwa Woda IG-1* & 920 & $625-856$ & 856 & 20 \\
\hline Szymoszkowa GT-1 & 861.49 & $1112-1737$ & 1737 & 27 \\
\hline Zakopane IG-1 & 864.9 & $1550-1620$ & 3073 & 26 \\
\hline Zakopane-2 & 871.2 & $1065-1113$ & 1113 & 22 \\
\hline Zazadnia IG-1*** & 855.2 & $665-680$ & 680 & 60.5 \\
\hline Furmanowa PIG-1* & 1010 & $2003-2324$ & 2324 & 67 \\
\hline Bukowina Tatrzańska PIG/PNiG-1 & 957 & $2390-2605$ & 3780 & 63 \\
\hline Poronin PAN-1* & 741 & $1768-1855$ & 3003 & 82 \\
\hline Chochołów PIG-1 & 778 & $3218-3547$ & 3572 & 77 \\
\hline Białka Tatrzańska GT-1 & 716.47 & $2112-2500$ & 2500 & 82 \\
\hline Biały Dunajec PAN-1** & 685 & $2117-2394$ & 2394 & 86 \\
\hline Biały Dunajec PGP-2** & 682.7 & $2040-2450$ & 2450 & 82 \\
\hline Bańska IG-1 & 679 & $2565-2683$ & 5261 & 86 \\
\hline Bańska PGP-1 & 672.3 & $2722-3242$ & 3242 & 85.5 \\
\hline Bańska PGP-3 & 672 & $2766-3384$ & 3400 & \\
\hline
\end{tabular}

* unused boreholes

** absorption boreholes

*** currently (2018) intake of common waters

All used and unused boreholes, both for production and absorption purposes, in which geothermal waters were found, are presented in Table 1, along with their basic characteristics. The temperature of geothermal waters in existing boreholes in the Podhale Basin ranges from $20^{\circ} \mathrm{C}$ (Siwa Woda IG-1) to $86^{\circ} \mathrm{C}$ (Biały Dunajec PGP-2 and Bańska PGP-1).

Under conditions undisturbed by exploitation, natural changes in the properties of geothermal waters are reported farther away from the feeding zone of deep groundwaters in the Tatra massif. The farther north from the northern edge of the Tatras, the temperature of water in the deposit increases, which results from the increasing depth of deposition of reservoir rocks (Fig. 2). Thus, geological structure and secondary occurrence of tectonic zones with privileged thermal conditions has an effect on the temperature of geothermal waters. Over 20 years of continuous operation has proved its stable operating parameters - a small drop in pressure and an unnoticeable temperature change (Chowaniec et al. 2007). Under theoretically natural conditions, geothermal step isolines run basically in parallel along an east-west axis, i.e. following the increasing distance from the feeding zone within the Tatras. This system was heavily disturbed with the conducted exploitation of geothermal waters, but also as a result of the geological inhomogeneity of the reservoir, existence of fault zones and privileged filtration roads.

\section{METHODS OF GEOTHERMAL STEP CALCULATION}

Disintegration of radioactive elements in the Earth's core is related to the release of significant quantities of heat. The temperature gradient follows its movement towards the surface of the Earth, called the geothermal gradient, defined as the value of the increase in temperature per unit of depth. For Poland, the average value of the temperature gradient $25^{\circ} \mathrm{C} / \mathrm{km}$ is accepted. The gradient varies and depends on the warm stream. In Poland, the absolute value of water temperature is determined with the surface changes in intensity of the normal heat flow of the Earth. The value of the heat flow ranges from $25-40 \mathrm{~mW} / \mathrm{m}^{2}$ in the Precambrian platform up to $50-90 \mathrm{~mW} / \mathrm{m}^{2}$ within the Palaeozoic platform and $50-80 \mathrm{~mW} / \mathrm{m}^{2}$ in the Alps orogen of the Carpathians (Bujakowski et al. 2016).

For Podhale, the density of the heat flow is estimated at $60-70 \mathrm{~mW} / \mathrm{m}^{2}$ and differs slightly from the average world density of geothermal energy stream of $60 \mathrm{~mW} / \mathrm{m}^{2}$ (Sobański et al. 2000). The average value of the geothermic gradient for the Carpathians is $23.5^{\circ} \mathrm{C} / 1000 \mathrm{~m}$ (Górecki 2010). The average geothermal gradient for the Podhale 
Basin and its base is lower than for other regions of the Carpathians and is in the range of 1.9$2.1^{\circ} \mathrm{C} / 100 \mathrm{~m}$ (Plewa 1994, Kępińska 1995, 1997).

Geothermal gradient gains in importance below the thermally neutral zone, where annual changes in temperatures disappear. Its value determines the possibility of the practical application of geothermal energy, for which a breakdown into geothermal regions is used:

- hyperthermal: with the temperature gradient over $80^{\circ} \mathrm{C} / \mathrm{km}$,

- demithermal: with the temperature gradient $40-80^{\circ} \mathrm{C} / \mathrm{km}$,

- normal: with the temperature gradient below $40^{\circ} \mathrm{C} / \mathrm{km}$.

The reciprocity of the geothermal gradient is the term of geothermal step, which means the number of meters for $1^{\circ} \mathrm{C}$ increase in temperature (Majorowicz 1977). Temperature down to the depth of $10 \mathrm{~km}$ changes approximately linearly (Plewa 1994), which may be presented in a general equation (Dowgiałło et al. 2002):

$T=t_{\mathrm{av}}+A+\frac{H-h}{g}$

where:

$T$ - temperature of water at the depth of $H\left[{ }^{\circ} \mathrm{C}\right]$,

$t_{\mathrm{av}}$ - average annual temperature on the surface $\left[{ }^{\circ} \mathrm{C}\right]$,

$A$ - correction dependent on the elevation above sea level $\left[{ }^{\circ} \mathrm{C}\right]$,

$H$ - the depth of occurrence of water [m],

$h$ - the depth of the zone of fixed temperatures [m],

$g$ - geothermal step [m].

\section{RESULTS}

With the formula (1) transformed for the geothermal boreholes listed in Table 1, the values of the average geothermal step were calculated:

$$
g=\frac{H-h}{T-t_{\mathrm{av}}-A}
$$

where:

$H$ - the middle point of the open casing (screen interval) of the boreholes according to Table $1[\mathrm{~m}]$,

$t_{\mathrm{av}}$ - average temperature on the surface, assumed at $6^{\circ} \mathrm{C}$,
$T$ - temperature of water at the outflow according to Table $1\left[{ }^{\circ} \mathrm{C}\right]$,

$h$ - the depth of the zone of fixed temperatures assumed at $20 \mathrm{~m}$,

$A$ - correction dependent on the elevation above sea level $\left[{ }^{\circ} \mathrm{C}\right]$ according to Table 2 .

Table 2

The value of A parameter in Equal (2) (Dowgiałto et al. 2002)

\begin{tabular}{|l|c|c|c|c|c|}
\hline Elevation [MASL] & 0 & 500 & 1,000 & 1,500 & 2,000 \\
\hline Value $\boldsymbol{A}\left[{ }^{\circ} \mathbf{C}\right]$ & 0.8 & 1.0 & 1.3 & 1.7 & 2.3 \\
\hline
\end{tabular}

The calculations of the average arithmetical geothermal step were conducted with the following assumptions:

- the value of changes in temperature is linearly dependent on the depth,

- for prospective investors, temperature at the outflow is economically justifiable and interesting, and not in the deposit,

- the depth of the abstracted waters is the simple average of the filtrated depth interval read from the intake profile.

For the boreholes abstracting geothermal waters in the area of the Podhale Basin, the value of the average geothermal step calculated according to the formula (2) ranges from $28 \mathrm{~m}$ up to $71 \mathrm{~m}$ of the depth corresponding with the increase in temperature by $1^{\circ} \mathrm{C}$ (Tab. 3, Fig. 4).

Table 3

Calculated geothermal step value for boreholes in Podhale Basin

\begin{tabular}{|l|c|}
\hline \multicolumn{1}{|c|}{ Borehole } & $\begin{array}{c}\text { Geothermal step } \\
{\left[\mathbf{m} / \mathbf{1}^{\circ} \mathbf{C}\right]}\end{array}$ \\
\hline Siwa Woda IG-1 & 57 \\
\hline Szymoszkowa GT-1 & 71 \\
\hline Zakopane IG-1 & 53 \\
\hline Zakopane-2 & 57 \\
\hline Zazadnia IG-1 & 44 \\
\hline Furmanowa PIG-1 & 40 \\
\hline Bukowina Tatrzańska PIG/PNiG-1 & 41 \\
\hline Poronin PAN-1 & 32 \\
\hline Chochołów PIG-1 & 45 \\
\hline Białka Tatrzańska GT-1 & 33 \\
\hline Biały Dunajec PAN-1 & 30 \\
\hline Biały Dunajec PGP-2 & 28 \\
\hline Bańska IG-1 & 35 \\
\hline Bańska PGP-1 & 38 \\
\hline Bańska PGP-3 & 39 \\
\hline
\end{tabular}




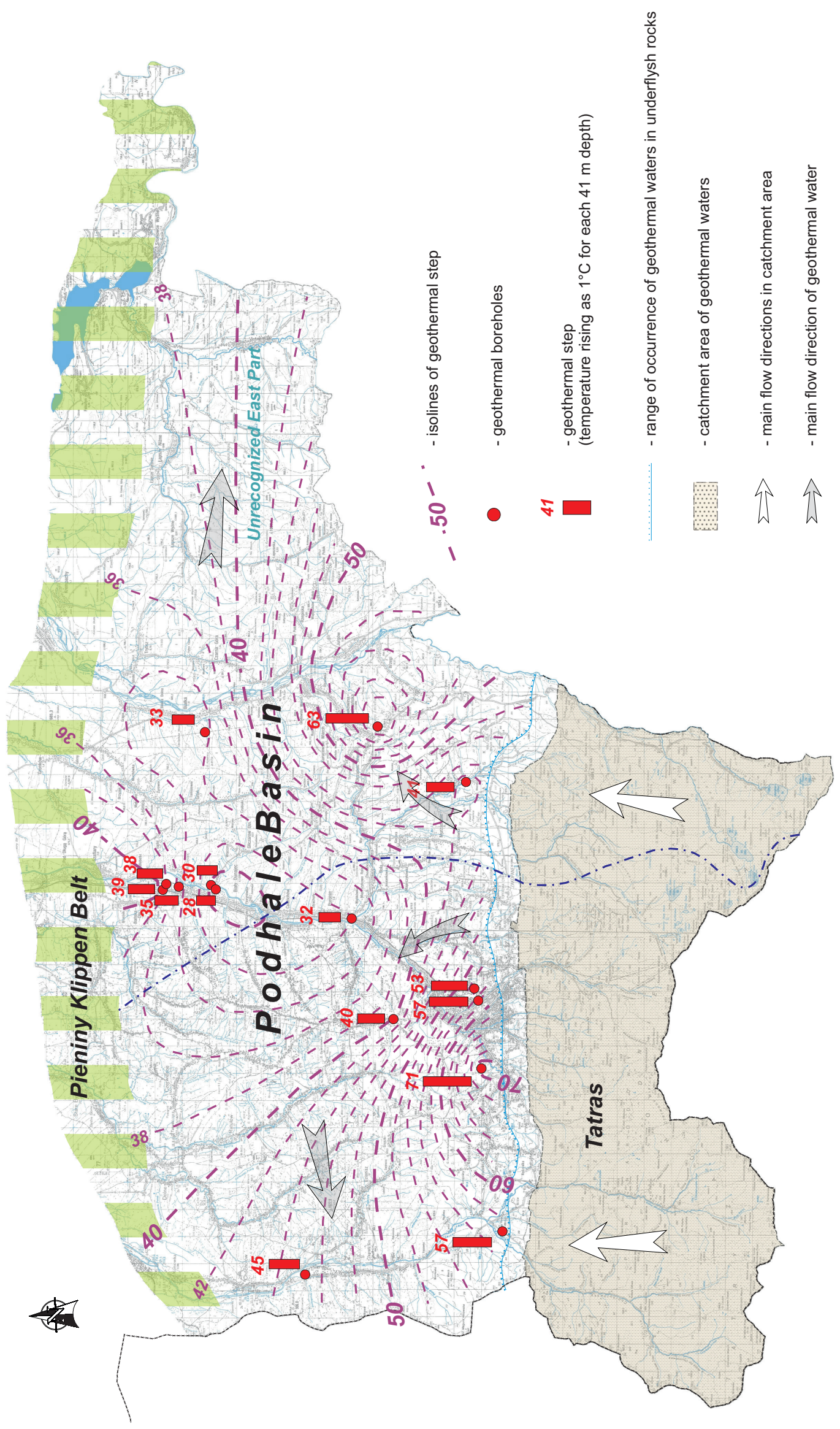


Based on the available data that characterise 15 completed boreholes abstracting thermal water in the area of the Podhale Basin, the average value of geothermal step was calculated for the given assumptions. The parameter is highly important from the point of view of using geothermal waters resources as information about the temperature of water at the outflow (i.e. practically manageable) and the depth of the prospective boreholes that is decisive for the costs of execution of the boreholes. The spatial variability of the geothermal step clearly confirms the expected increase in temperature (thus: the lower values of geothermal step) along with moving away from the Tatras to the Pieniny Klippen Belt (Fig. 4).

\section{DISCUSSION AND CONCLUSION}

The completed analysis and the resulting map of the distribution of the geothermal step allows us to make a preliminary assessment of the current possibilities of using resources of geothermal waters of the Podhale Basin and selecting the places that are potentially optimum in terms of temperature. The natural expected temperature of waters in the deposit and at the outflow is usually the first criterion decisive for further concept work. Actions improving the conditions of exploitation are also technically possible at the stage of execution of the intake. The actual temperature of water at the outflow, and most of all the increase of the capacity of the boreholes, may be significantly dependent on, among others, the acidification procedures carried out. It is estimated that an increase in temperature is dependent on an increase in capacity which may range from several degrees up to over $30^{\circ} \mathrm{C}$ (Chowaniec et al. 2001). However, the initial and basic criterion is still the temperature of waters in the deposit and at the intake, as well as their depth. Both pieces of information are included in the parameter termed the geothermal step, whose values and spatial variability were assessed based on the current hydrogeological search. The presented analysis may be implemented in other areas of Poland, where projects of the abstraction of geothermal waters are planned for recreation and rehabilitation complexes. Spatial variability of geothermal step/gradient, thus the expected temperature of water at the planned depth, are the basic parameters that determine the success and profitability of the project. Disturbances resulting from the conducted exploitation change the natural distribution of geothermal step isolines, which is clearly seen in Figure 4. Providing analysis corresponds with the procedure presented in this paper, errors may be avoided in other areas of Poland related to overestimating the expected temperature of geothermal waters.

\section{REFERENCES}

Barbacki A., 2012. Classification of geothermal resources in Poland by exergy analysis - Comparative study. Renewable and Sustainable Energy Reviews, 16, 1, 123-128, DOI: http://dx.doi.org/10.1016/j.rser.2011.07.141.

Bertani R., 2016. Geothermal power generation in the world 2010-2014 update report. Geothermics, 60, 31-43, DOI: http://dx.doi.org/10.1016/j.geothermics.2015.11.003.

Bugajski P., Nowobilska-Majewska, E., Nowobilska-Luberda A. \& Bergel T., 2017. The use of geothermal waters in Podhale in terms of tourism and industrial applications. Journal of Ecological Engineering, 18, 6, 185-191, DOI: https://doi.org/10.12911/22998993/75692.

Bujakowski W., 2005. The review of Polish experiences in the use of geothermal water. [in:] Proceedings of the World Geothermal Congress 2005: Antalya, Turkey, 24-29 April 2005. Geothermal energy, the domestic, renewable, green option, International Geothermal Association, Auckland, N.Z. 1-9.

Bujakowski W. \& Barbacki A., 2004. Potential for geothermal development in Southern Poland. Geothermics, 33, 3, 383-395, DOI: http://dx.doi.org/10.1016/j.geothermics.2003.04.001.

Bujakowski W., Tomaszewska B. \& Miecznik M., 2016. The Podhale geothermal reservoir simulation for long-term sustainable production. Renewable Energy, 99, 420-430, DOI: http://dx.doi.org/10.1016/j.renene.2016.07.028.

Chowaniec J., 2009. Hydrogeology study of the western part of the Polish Carpathian. Biuletyn Państwowego Instytutu Geologicznego, 734, 1-98.

Chowaniec J., Małecka D. \& Witczak S., 1998. Hydrochemical characterization of ground waters of the arthral basin of Podhale. Przeglad Geologiczny, 46, 1, 42-43.

Chowaniec J., Poprawa D. \& Witek K., 2001. Occurrence of thermal waters in the Polish Carpathians (southern Poland). Przegląd Geologiczny, 49, 8, 734-742.

Chowaniec J., Zuber A. \& Ciężkowski W., 2007. Prowincja karpacka. [in:] Paczyński B. \& Sadurski A. (red.), Hydrogeologia regionalna Polski. T. 2, Wody mineralne, lecznicze $i$ termalne oraz kopalniane, Państwowy Instytut Geologiczny, Warszawa, 78-96.

Directive, 2009. Directive 2009/28/EC of the European Parliament and of the Council of 23 April 2009 on the promotion of the use of energy from renewable sources and amending and subsequently repealing Directives 2001/77/ EC and 2003/30/EC. Official Journal of the European Union, L 140/16, 5.6.2009. 
Długosz P., 2003. Podhale (South Poland) geothermal district heating system. Geothermics, 42, 4-6, 527-533, DOI: http://dx.doi.org/10.1016/S0375-6505(03)00064-6.

Dowgiałło J., Kleczkowski A.S., Macioszczyk T. \& Różkowski A. (red.), 2002. Stownik hydrogeologiczny. Wyd. 2. Państwowy Instytut Geologiczny, Warszawa.

Górecki W., 2010. Wody geotermalne na Niżu Polskim. Przeglad Geologiczny, 58, 7, 574-579.

Gudmundsson J., Freeston D. \& Lienau P., 1985. The Lindal Diagram. GRC Transactions, 9, 15-17.

Huculak M., Jarczewski W. \& Dej M., 2015. Economic aspects of the use of deep geothermal heat in district heating in Poland. Renewable and Sustainable Energy Reviews, 49, 29-40, DOI: http://dx.doi.org/10.1016/j.rser.2015.04.057.

Igliński B., Buczkowski R., Kujawski W., Cichosz M. \& Piechota G., 2012. Geoenergy in Poland. Renewable and Sustainable Energy Reviews, 16, 5, 2545-2557, DOI: http://dx.doi.org/10.1016/j.rser.2012.01.062.

Igliński B., Piechota G., Iglińska A., Cichosz M. \& Buczkowski R., 2016. The study on the SWOT analysis of renewable energy sector on the example of the Pomorskie Voivodeship (Poland). Clean Technologies and Environmental Policy, 18, 1, 45-61, DOI: http://dx.doi.org/10.1007/s10098015-0989-7.

Kepinska B., 2000. The Podhale low-enthalpy system (S-Poland): geothermal characteristics. [in:] Proceedings of the World Geothermal Congress, 2000: Kyushu-Tohoku, Japan, May 28-June 10, 2000, Japanese Organizing Committee for WGC 2000, Tokyo, Japan; International Geothermal Association, Auckland, N.Z., 1343-1348.

Kepinska B., 2003. Current geothermal activities and prospects in Poland - an overview, Geothermics, 32, 4, 397-407, DOI: http://dx.doi.org/10.1016/j.geothermics. 2003.07.006.

Kepinska B., 2015. Geothermal energy country update report from Poland, 2010-2014. [in:] World Geothermal Congress, 16-24 April 2015, Australia-New Zealand: Proceedings, International Geothermal Association.

Kępińska B., 1995. Temperatura głównego poziomu wodonośnego pola geotermalnego Podhala. Technika Poszukiwań Geologicznych Geosynoptyka i Geotermia, 34, 3-14.

Kępińska B., 1997. Model geologiczno-geotermalny niecki podhalańskiej. Studia Rozprawy Monografie, nr 48, Wyd. CPPGSMiE PAN, Kraków.

Kępińska B., 2009. Znaczenie badań podhalańskiego systemu geotermalnego dla eksploatacji wód geotermalnych. Technika Poszukiwań Geologicznych, 48, 2, 29-48.

Kotowski T. \& Satora S., 2011. Conception of the desalination plant at Bańska Niżna - usability of a post-process concentrate. Biuletyn Państwowego Instytutu Geologicznego, 445, 309-316.

Kotowski T. \& Satora S., 2012. Wpływ eksploatacji wód termalnych na zmiany ich chemizmu oraz możliwości wykorzystania na przykładzie Bańskiej Niżnej. Gaz Woda i Technika Sanitarna, 8, 338-341.
Lewandowski W.M., 2007. Proekologiczne odnawialne źródła energii. Wydawnictwa Naukowo-Techniczne, Warszawa.

Majorowicz J., 1977. Analiza pola geotermicznego Polski na tle Europy ze szczególnym uwzględnieniem zagadnień tektonicznych i hydrogeotermalnych. Przeglad Geologiczny, 3, 135-143.

Małecka D., 2003. The thermal waters of Podhale, southern Poland: history of research, genesis and utility. Geological Quarterly, 47, 2, 195-209.

Obwieszczenie, 2010. Obwieszczenie Ministra Gospodarki $z$ dnia 21 grudnia 2009 r. w sprawie polityki energetycznej państwa do $2030 \mathrm{r}$. [Energy Policy of Poland up to 2030]. M.P. 2010, nr 2, poz. 11.

Operacz A., 2017. The term "effective hydropower potential" based on sustainable development - an initial case study of the Raba river in Poland. Renewable and Sustainable Energy Reviews, 75, 1453-1463, DOI: http://dx.doi. org/10.1016/j.rser.2016.11.141.

Plewa S., 1994. Rozkład parametrów geotermicznych na obszarze Polski. Wydawnictwo CPPGSMiE PAN, Kraków.

Sobański R., Kabat M. \& Nowak W., 2000. Jak pozyskać ciepło z Ziemi? Centralny Ośrodek Informacji Budownictwa, Warszawa.

Sokołowski S., 1973. Geologia paleogenu i mezozoicznego podłoża południowego skrzydła niecki podhalańskiej w profilu głębokiego wiercenia w Zakopanem. Biuletyn - Instytut Geologiczny, 265, 5-74.

Szewczyk J. \& Gientka D., 2009. Terrestrial heat flow in Poland - a new approach. Geological Quarterly, 53, 1, 125140.

Tomaszewska B., 2009. Uzdatnianie wód termalnych ujętych otworem Bańska IG-1 do celów pitnych jako jeden z kierunków ich kompleksowego wykorzystania. Technika Poszukiwań Geologicznych, 48, 2, 21-28.

Tomaszewska B. \& Bodzek M., 2013. Desalination of geothermal waters using a hybrid UF-RO process. Part I: boron. removal in pilot-scale tests. Desalination, 319, 99-106, DOI: https://doi.org/10.1016/j.desal.2012.05.029.

Tomaszewska B. \& Pająk L., 2012. Geothermal water resources management - economic aspects of their treatment. Gospodarka Surowcami Mineralnymi - Mineral Resources Management, 28, 4, 59-70, DOI: https://doi. org/10.2478/v10269-012-0038-7.

Tomaszewska B. \& Szczepański A., 2014. Possibilities for the efficient utilisation of spent geothermal waters. Environmental Science and Pollution Research, 21, 19, 1140911417, DOI: https://doi.org/10.1007/s11356-014-3076-4.

Ustawa, 2011. Ustawa $z$ dnia 9 czerwca 2011 r. - Prawo geologiczne i górnicze [Geological and Mining Act]. Dz.U.2011, nr 163, poz. 981 z późn. zm.

Zdechlik R., Tomaszewska B., Dendys M. \& Pająk L., 2015. Przegląd oprogramowania do numerycznego modelowania procesów środowiskowych w systemach geotermalnych. Przegląd Geologiczny, 63, 1150-1154. 